http://journal.nafo.int

J. Northw. Atl. Fish. Sci., Vol. 22: 137-154

\title{
Predation by Harp Seals in Atlantic Canada: Preliminary Consumption Estimates for Arctic Cod, Capelin and Atlantic Cod
}

\author{
G. B. Stenson \\ Department of Fisheries and Oceans, Science Branch \\ P. O. Box 5667, St. John's, Newfoundland Canada A1C 5X1 \\ M. O. Hammill \\ Department of Fisheries and Oceans, Science Branch \\ P. O. Box 1000, Mont Joli, Quebec Canada G5H 3 Z4 \\ and \\ J. W. Lawson \\ Ocean Sciences Centre, Memorial University of Newfoundland \\ St. John's, Newfoundland Canada A1C 5S7
}

\begin{abstract}
Current estimates of harp seal (Phoca groenlandica) abundance indicate that the total population size in eastern Canada in 1994 was approximately 4.8 million (95\% C.I. $4.1-$ 5.0 million) animals. To estimate the consumption of important fish prey by harp seals off the coast of Newfoundland and in the Gulf of St. Lawrence, a model incorporating agespecific estimates of energy requirements, population size, seasonal distribution and diets was developed. Total annual prey consumption increased from 3.6 million to 6.9 million tons between 1981 and 1994. The proportions of prey obtained in the Arctic and eastern Newfoundland/southern Labrador areas were $46 \%$ and $40 \%$, respectively, while $14 \%$ was consumed in the Gulf of St. Lawrence. Arctic cod (Boreogadus saida) and capelin (Mallotus villosus) were the major prey off eastern Newfoundland while capelin was the most important in the Gulf. Based on an average diet, harp seals consumed an estimated total of 2.8 million tons, including 1.2 million tons (95\% C.I. 735 000-1.7 million) of Arctic cod, 620000 tons (95\% C.I. $288000-1.0$ million) of capelin and 88000 tons (95\% C.I. 46000 140 000) of Atlantic cod (Gadus morhua) off the eastern coast of Newfoundland in 1994. In the Gulf, harp seals consumed an estimated 445000 tons (95\% C.I. 208 000-727 000) of capelin, 20000 tons (95\% C.I. 0-48 000) of Arctic cod, and 54000 tons (95\% C.I. $14000-102000$ ) of Atlantic cod out of a total of 961000 tons of prey. Incorporating seasonal, geographic and annual variations in the diet provided additional information on trends in consumption. Basic assumptions of the model were varied to assess its sensitivity. Changes in the energetic costs of activity and growth, abundance, residency period, or the proportion of energy obtained from offshore areas can affect estimates of total consumption significantly.
\end{abstract}

Key words: Arctic cod, Atlantic cod, capelin, consumption, Gulf of St. Lawrence, harp seal, model, Newfoundland, Northwest Atlantic, Phoca groenlandica, predation.

\section{Introduction}

Harp seals (Phoca groenlandica) are a migratory species found throughout the North Atlantic where they feed upon a variety of fish and invertebrate species (Sergeant, 1973, 1991; Smith et al., 1979; Beck et al., 1993; Lawson and Stenson, 1995, in press; Kapel, 1995; Lawson et al., 1995). Recent studies indicate that their numbers have been increasing in the Northwest Atlantic since the early 1970s and were in the order of 4.5-4.8 million in 1994 (Shelton et al., 1996). The impact of this abundant predator on commercial fish stocks off the Atlantic coast of Canada is unknown. Before a 
possible impact can be assessed, however, the total amount of each of these prey species consumed must be estimated.

Consumption of fish by marine mammal predators has been estimated by a number of authors using bioenergetic models (Øritsland and Markussen, 1990; Ryg and Øritsland, 1991; Markussen and Øritsland, 1991; Olesiuk, 1993; Hammill and Mohn, MS 1994; Mohn and Bowen, 1996; Nordøy et al., 1995a,b). These models assume that the amount of prey consumed is equal to the energy requirements of the predators. The energy requirements of individual seals are first estimated and then extrapolated to the entire population. The proportion of energy obtained from various prey species and the amount consumed is then estimated using information on the seasonal distribution of seals, the composition of their diet in various areas, and the energy content of the prey.
Although the general migratory pattern has been determined from marine mammal surveys, catch records, aerial observations and anecdotal sightings (Sergeant, 1965, 1991; Stenson and Kavanagh, 1993; Stenson, Northwest Atlantic Fisheries Center, St. John's, Canada, unpubl. data), detailed knowledge of the seasonal distribution of harp seals in the Northwest Atlantic is limited. Generally, they spend the summer in Arctic waters, primarily the Canadian Arctic and West Greenland, and migrate southward in the late autumn (Fig. 1). When they reach the Strait of Belle Isle, some seals remain off the east coast of Newfoundland while others move into the Gulf of St. Lawrence. They form large whelping concentrations in late February/early March off southern Labrador or near the Magdalen Islands in the Gulf of St. Lawrence. Following breeding, seals disperse briefly. From mid April to mid May they congregate into large moulting concentrations and after the moult they eventually

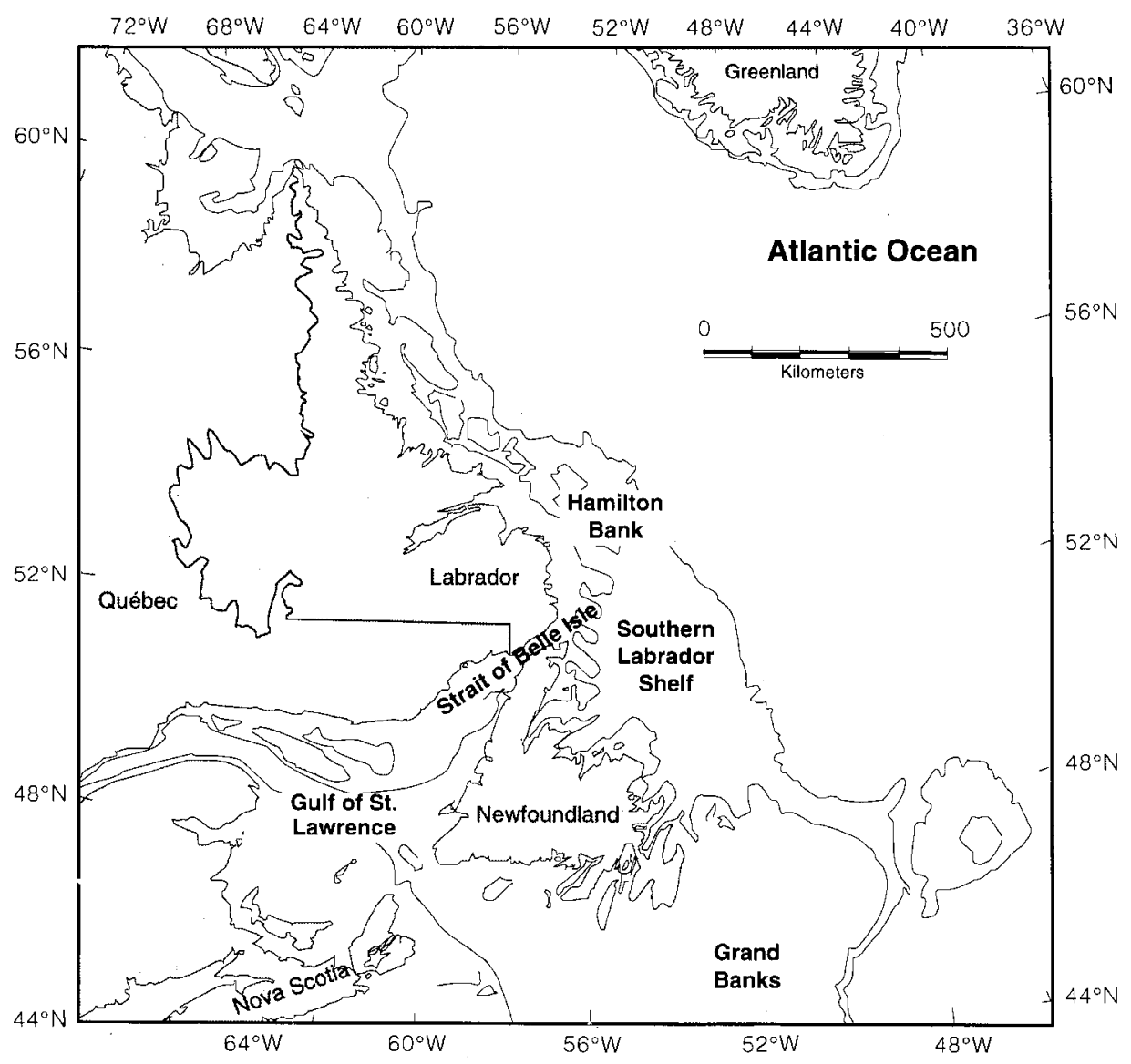

Fig. 1. Map of the study area showing place names mentioned in the text. 
migrate northward. The timing of the migrations appears to be variable and may be influenced by prey availability, ice cover, or water temperature.

Traditionally, harp seals were considered to be primarily a nearshore species (e.g. Sergeant, 1991). However, this was based on information such as catch statistics and tag returns that were biased towards nearshore areas. Recent studies indicate that harp seals are also present in offshore waters (Stenson and Kavanagh, 1993; Stenson and Sjare, MS 1997) where they have been observed distributed across the southern Labrador Shelf and Grand Banks out to the $400 \mathrm{~m}$ depth contour during the spring and winter. However, the proportion of the population present in these areas has not been estimated.

The objective of this study was to estimate total prey consumption by harp seals in the Northwest Atlantic from 1981 to 1994 using a bioenergetics model. In addition, we estimated the amount of Arctic cod (Boreogadus saida), capelin (Mallotus villosus) and Atlantic cod (Gadus morhua) consumed by harp seals in the waters off eastern Newfoundland south of $55^{\circ} \mathrm{N}$ and in the Gulf of St. Lawrence. To illustrate the sensitivity of the results to the basic parameters used in the model, consumption estimates were compared using different assumptions of population size, energy requirements for activity and growth, seasonal distribution, and annual, seasonal and geographic variation in the diet.

\section{Materials and Methods}

\section{Model Inputs}

Abundance. Shelton et al. (1996) presented estimates of numbers-at-age for Northwest Atlantic harp seals from 1955 to 1994 (Fig. 2). Under the assumption that mortality was constant for all age groups, the model used for these estimates indicated that the population declined from an estimated 2.8 million seals in 1955 to approximately 1.8 in the early-1970s. Since then it has increased, from approximately 2.5 million in 1981 to approximately 4.8 million (range 4.1-5.0) in 1994. This population trajectory was used in the initial run of the model.

In a second run of the model, Shelton et al. (1996) assumed that pup mortality was greater than that of older seals. The resulting population was lower, reaching an estimated 4.5 million in 1994 (Fig. 1). To determine the importance of population size, consumption in southern Atlantic waters (Gulf

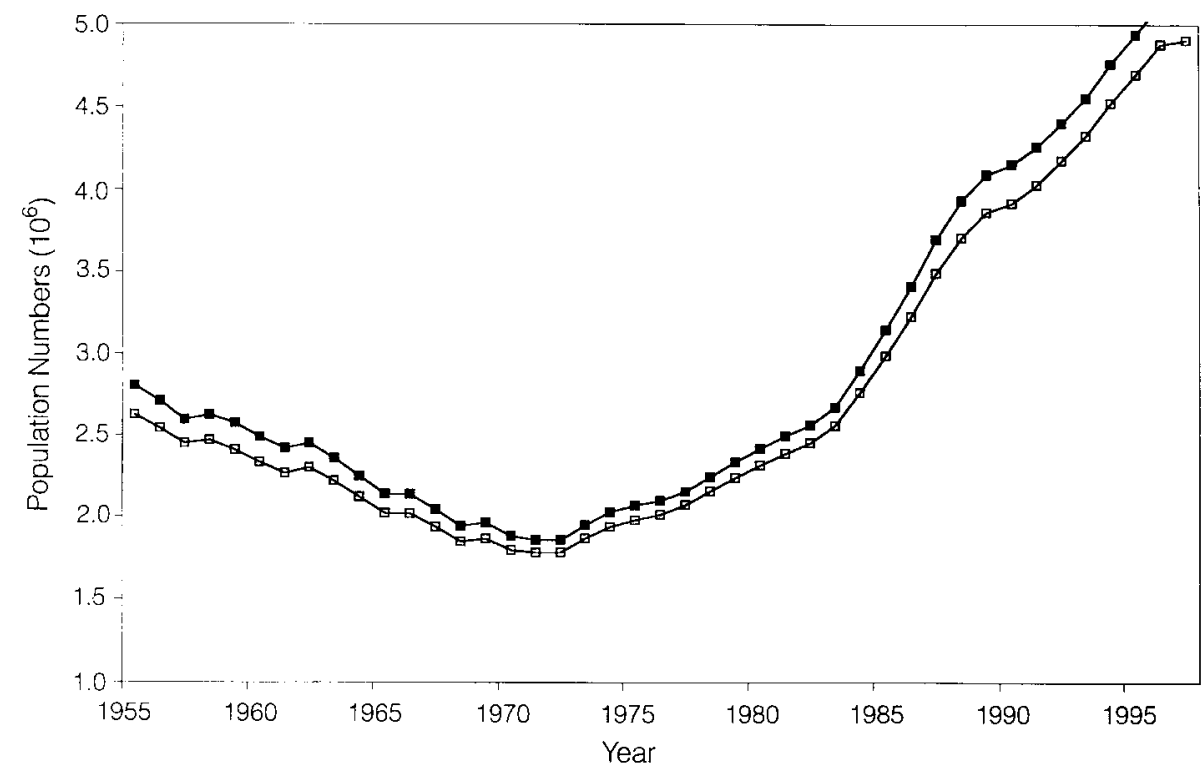

Fig. 2. Estimated abundance of Northwest Atlantic harp seals assuming pup mortality is equal to that of adults ( $\square$ ) or three times that of adults ( $\square$ ). From Shelton et al. (1996). 
of St. Lawrence and eastern Newfoundland) was also estimated using the lower population estimate.

Seasonal distribution. In this study, the Northwest Atlantic was divided into three regions and the proportion of energy obtained from each one was estimated using the proportion of time assumed to be spent in each region. The area north of Hamilton Bank $\left(55^{\circ} \mathrm{N}\right.$; Fig. 2), including the Canadian Arctic, Greenland and northern Labrador, was classified as the Arctic. The region south of $55^{\circ} \mathrm{N}$ and encompassing inshore areas along the coast of southern Labrador and eastern Newfoundland, and offshore areas of the southern Labrador shelf and Grand Banks of Newfoundland is referred to as eastern Newfoundland. The Gulf of St. Lawrence includes all areas of the Gulf including the west coast of Newfoundland up to the Strait of Belle Isle. The Arctic region approximates NAFO convention Subareas 0 and 1 and Div. 2G, while the Eastern Newfoundland region consists of Div. $2 \mathrm{~J}$ and $3 \mathrm{KL}$ and those components of Div. 3NO that occur on the Grand Banks. The Gulf region includes NAFO Div. 4RST.

The total annual energy required by adults (animals older than four years of age) and pups or juveniles (aged one to four years) was divided into two seasons (October-March and April-September), roughly corresponding to the periods of primarily southern and northern distribution. For each season, the proportions of the total energy requirements obtained from each of three areas (eastern Newfoundland, Gulf of St. Lawrence, and Arctic; Table 1) were estimated assuming that:

a) harp seals enter the area south of $55^{\circ} \mathrm{N} 15$ November and leave 15 June (212 days).

b) $20 \%$ of juveniles and pups remain in the Arctic throughout the year (Anon., 1986; Kapel, 1982; Larsen, MS 1985). c) $25 \%$ of the population is present in the Gulf of St. Lawrence between 1 December and 31 May.

d) $5 \%$ of the seals remain in the study area throughout the year; $25 \%$ of these seals stay in the Gulf while $75 \%$ stay off eastern Newfoundland.

In recent years, seals have been reported to arrive along the coast of Newfoundland earlier in the autumn and to remain longer before migrating northward. To estimate the importance of a longer residency time, in an alternative run of the model was used to estimate Newfoundland and Gulf of St. Lawrence consumption after increasing the residency period in southern areas (south of $55^{\circ} \mathrm{N}$ ) by one month (1 November-30 June).

Energy Requirements. Energy requirements were assumed to be constant throughout the year. Age-specific energy requirements were calculated using an allometric relationship linked to mass-atage based on Kleiber (1975). Corrections for the additional energy requirements associated with activity and growth of juveniles were included:

$$
G E I_{i}=G P_{i} \times\left(A F \times 70 \times B M_{i}^{0.75}\right) /(M E)
$$

where $G E I$ is the average daily gross energy intake, $i$ is the age group, GP is the increased energy required for young animals, $A F$ is the activity factor, $B M$ is the mean body mass for age group $(\mathrm{kg})$, and $M E$ is the proportion of gross energy intake available to the animal.

The body mass $(B M)$ was based on measurements obtained from seals collected during April 1979-94 (Table 2). The proportion of energy contained in the food which is available to the animal $(M E)$ has been estimated to be $0.85-0.88$ for juvenile harp seals fed herring (Keiver et al., 1984), 0.83 for grey seals (Ronald et al., 1984) and 0.827 for

TABLE 1. Assumed proportions of the annual energy budget obtained by harp seals from different geographic regions during 'Winter' (October-March) and 'Summer' (April-September) periods.

\begin{tabular}{|c|c|c|c|c|}
\hline & \multicolumn{2}{|c|}{ Pups/Juveniles } & \multicolumn{2}{|c|}{ Adults } \\
\hline & Winter & Summer & Winter & Summer \\
\hline Newfoundland & 0.23 & 0.14 & 0.29 & 0.18 \\
\hline Gulf & 0.07 & 0.04 & 0.09 & 0.04 \\
\hline Arctic & 0.20 & 0.32 & 0.12 & 0.28 \\
\hline Total & 0.50 & 0.50 & 0.50 & 0.50 \\
\hline
\end{tabular}


ringed seals (Ryg and Øritsland, 1991). Based upon the composition of the diet of harp seals in Newfoundland (Lawson et al., 1995; Lawson and Stenson,1997), and a weighted average of digestive efficiencies for various prey (Lawson et al., 1997, 1998), an estimated $M E$ of 0.83 was assumed for the model.

Studies of the energy requirements of captive and wild seals indicate that the estimates of the average daily energy requirements vary between 1.7 and 3 times the basal metabolic rate estimated from body mass (Worthy, 1990). An $A F$ of 2 was chosen to approximate the energy requirements of freeranging seals. To investigate the importance of this assumption, total Newfoundland and Gulf of St. Lawrence consumption was also estimated using an $A F$ of 2.5 .

The increased energy required by younger animals primarily for growth $(G P)$, was applied to the metabolic calculations based on estimates obtained from Øritsland and Markussen (1990; Table 3). The influence of this assumption was examined by estimating Newfoundland and Gulf of St. Lawrence consumption using the slightly lower energy costs for young animals proposed by Olesiuk (1993) for harbour seals (Table 3 ).

Composition of Harp Seal Diets. The species composition of the diet was determined by identifying hard parts in the stomachs of seals. The proportions of each prey species consumed was esti-

TABLE 2. Mean body weights of male and female harp seals collected during April, 1979-94 (Chabot et al., 1996). This sample includes only seals for which total body mass were available.

\begin{tabular}{rcr}
\hline \hline $\mathrm{n}$ & Age $(\mathrm{yrs})$ & Weight $(\mathrm{kg})$ \\
\hline 592 & 0 & 25.5 \\
501 & 1 & 45.8 \\
399 & 2 & 56.0 \\
359 & 3 & 64.8 \\
304 & 4 & 74.9 \\
293 & 5 & 82.3 \\
215 & 6 & 85.4 \\
169 & 7 & 92.8 \\
86 & 8 & 93.5 \\
89 & 9 & 96.5 \\
375 & $10+$ & 101.8 \\
Total $=3382$ & & Mean $=65.0$ \\
\hline
\end{tabular}

mated by reconstructing the wet weights of the prey ingested using either undigested remains or species specific weight/otolith regressions (for examples see Murie and Lavigne, 1991; Beck et al., 1993; Lawson et al., 1995; Lawson and Stenson, 1995, 1997).

The average proportion of Arctic cod, capelin and Atlantic cod and the mean energy density of the prey in the diet of harp seals feeding in the Gulf of St. Lawrence were estimated from five samples of stomach contents (Table 4). Two small samples were collected from the St. Lawrence Estuary in winter (January-February 1983; Murie and Lavigne, 1991) and spring (April 1988-90; Beck et al., 1993), while a third, larger, sample was collected during the breeding period around the Magdalen Islands (Beck et al., 1993). The two remaining samples were from seals collected along the west and southwest coasts of Newfoundland (Lawson and Stenson, 1995; Memorial University of Newfoundland, St. John's, Canada, unpubl. data), primarily between 1985 and 1993 .

A greater amount of data was available on the diet of harp seals feeding in the waters off southern Labrador and eastern Newfoundland. In this area, stomach collections were carried out annually between 1981 and 1994 (Lawson and Stenson, 1995, 1997; Lawson et al., 1995). Samples were collected in all months, with the majority taken between November and June. The majority of samples were taken in nearshore areas, but in recent years (199294) samples were also obtained from offshore areas (>100 km from shore), primarily along the northern edge of the Grand Banks during winter and on the bank during the spring. The proportion of stomachs containing a particular prey item (prevalence) was estimated for all years.

TABLE 3. Incremental energy required by young animals $(G P)$.

\begin{tabular}{ccc}
\hline \hline $\begin{array}{c}\text { Age } \\
\text { (years) }\end{array}$ & $\begin{array}{c}\text { Øritsland and } \\
\text { Markussen, 1990 }\end{array}$ & Olesiuk, 1993 \\
\hline 0 & 2.25 & 1.8 \\
1 & 2.0 & 1.6 \\
2 & 1.75 & 1.42 \\
3 & 1.5 & 1.26 \\
4 & 1.25 & 1.13 \\
5 & 1.0 & 1.05 \\
$6+$ & 1.0 & 1.0 \\
\hline
\end{tabular}


For the years 1982, 1986 and 1990-94, the contribution of each prey species to the diet was estimated by reconstructing the wet weights of prey ingested. Since the diet of harp seals off eastern Newfoundland varies annually, seasonally and geographically (Lawson and Stenson, 1995; Lawson et al., 1995), the data were divided into two seasons (winter: October-March and summer: AprilSeptember), and into nearshore and offshore components (Table 5). Annual estimates of the diet were available during both seasons for the nearshore component. However, due to small samples sizes, the offshore component was pooled across years and a single diet for each season used for all years. The average diet of harp seals in eastern Newfoundland was estimated by averaging the proportion of Arctic cod, capelin, Atlantic cod, and the mean energy density of the prey, from these 14 (12 nearshore, 2 offshore) samples.

For the initial run of the model, average diets for the Gulf of St. Lawrence and eastern Newfoundland were applied to all years and seasons (Table 6). To estimate the variance associated with the proportion of each prey type in the diet and the energy density of the prey, the $95 \%$ confidence limits were

TABLE 4. Estimates of the percent wet weight of Atlantic cod, capelin and Arctic cod in the diet of harp seals from the Gulf of St. Lawrence. $\mathrm{N}$ = number of stomachs containing food.

\begin{tabular}{|c|c|c|c|c|c|c|}
\hline & Escoumins $^{1}$ & Escoumins $^{2}$ & $\begin{array}{l}\text { Magdalen } \\
\text { Islands }^{3}\end{array}$ & $\begin{array}{l}\text { Newfoundland } \\
\text { SW Coast }\end{array}$ & $\begin{array}{l}\text { Newfoundland } \\
\text { West Coast }\end{array}$ & Average \\
\hline Atlantic cod & 1.0 & - & - & 13.8 & 13.2 & 5.6 \\
\hline Capelin & 77.0 & 98.0 & - & 28.2 & 28.4 & 46.3 \\
\hline Arctic cod & - & - & - & 0.07 & 10.1 & 2.0 \\
\hline Energy (kcal/g) & 1.8 & 1.5 & 1.2 & 1.3 & 1.6 & 1.5 \\
\hline $\mathrm{N}$ & 25 & 9 & 62 & 126 & 241 & \\
\hline
\end{tabular}

Samples collected January and February 1983; Murie and Lavigne, 1991

Samples collected April 1988-90; Beck et al., 1993

Samples collected March 1988-90; Beck et al., 1993

4 Samples collected November-June 1985-93; Lawson and Stenson, 1995; Memorial University of Newfoundland, St. John's, Canada, unpubl. data

TABLE 5. Estimates of the percent wet weight of Atlantic cod, capelin and Arctic cod in the diet of harp seals from Div. 2J and 3KL during summer and winter. $\mathrm{N}=$ number of stomachs containing food.

\begin{tabular}{|c|c|c|c|c|c|c|c|c|}
\hline & \multirow[b]{2}{*}{ Prey Species } & \multicolumn{6}{|c|}{ Nearshore } & \multirow{2}{*}{$\begin{array}{c}\text { Offshore } \\
\text { (1992-94) }\end{array}$} \\
\hline & & 1982 & 1986 & 1990 & 1991 & 1992 & 1993 & \\
\hline \multirow[t]{3}{*}{ Summer } & Atlantic cod & 1.31 & 1.37 & 2.68 & 0.75 & 2.13 & 3.46 & 8.60 \\
\hline & Capelin & 67.84 & 8.25 & 31.79 & 7.47 & 6.05 & 2.09 & 28.60 \\
\hline & Arctic cod & 5.10 & 74.67 & 42.24 & 40.43 & 34.95 & 41.08 & 0.55 \\
\hline Mean Energy Density & $(\mathrm{kcal} / \mathrm{g})$ & 1.27 & 1.31 & 1.41 & 1.47 & 1.57 & 1.35 & 1.30 \\
\hline $\mathrm{N}$ & & 88 & 101 & 71 & 77 & 60 & 47 & 160 \\
\hline \multirow[t]{3}{*}{ Winter } & Atlantic cod & 0.23 & 0.48 & 8.11 & 4.33 & 8.52 & 0.64 & 1.40 \\
\hline & Capelin & 82.46 & 1.96 & 5.93 & 0.88 & 11.89 & 5.41 & 50.40 \\
\hline & Arctic cod & 2.68 & 87.31 & 61.38 & 68.04 & 58.94 & 77.14 & 2.00 \\
\hline Mean Energy Density & $(\mathrm{kcal} / \mathrm{g})$ & 1.42 & 1.03 & 1.30 & 1.29 & 1.28 & 1.30 & 1.40 \\
\hline $\mathrm{N}$ & & 202 & 442 & 172 & 117 & 158 & 57 & 112 \\
\hline
\end{tabular}


approximated using a bootstrapping procedure in which the possible diets (14 for eastern Newfoundland and 5 for the Gulf of St. Lawrence) were resampled with replacement 1000 times. (Efron, 1982; Efron and Tibshirani, 1993).

To illustrate the importance of annual, seasonal and geographic variations in the diet, the proportion of each species present in the 14 diet samples for which reconstructed weights were available (Table 5), were used in model separately. The proportion of prey in the nearshore diet for years for which reconstructed wet weights were not available (1981, 1982-85, 1987-89) were estimated using prey-specific regressions of prevalence and wet weight calculated by using data from the six years for which both were available (Table 7). Due to variance around the regression, the total weight estimates for Atlantic cod, capelin and Arctic cod were occasionally greater than $100 \%$. To correct for this problem, all weight percentages were adjusted so that the total weight accounted for by these three species was equal to the mean values for the ap- propriate season (summer: mean $=72.5 \%, \mathrm{SE}=$ 4.2 and winter: mean $=84.17 \%, \mathrm{SE}=2.04)$. The regression-derived estimates of wet weight of the three prey species are summarised in Table 8 .

In order to incorporate geographical variation the diet, the proportion of the total annual energy intake in different areas must be estimated. Since our understanding of the seasonal distribution of harp seals is too limited to determine this, it was assumed that the amount of energy obtained from areas represented by the nearshore or offshore diets were equal.

\section{Consumption Estimates}

Total consumption of prey in each of the three areas (Arctic, eastern Newfoundland and Gulf of St. Lawrence) was estimated using the parameters described above. Studies of the diet of harp seals in Arctic areas indicate that Arctic cod, capelin, and pelagic crustaceans were important prey species (Smith et al., 1979; Kapel, 1995). Since this is similar to the diet observed in eastern Newfoundland,

TABLE 6. Mean and bootstrapped (1 000 iterations) estimates of $95 \%$ confidence limits of the percent wet weights of Atlantic cod, capelin and Arctic cod in harp seal diets based on 14 samples from Newfoundland and 5 samples from the Gulf of St. Lawrence (Tables 4 and 5).

\begin{tabular}{lcccc}
\hline \hline Prey Species & $\begin{array}{c}\text { Mean \% } \\
\text { Weight }\end{array}$ & $\begin{array}{c}\text { Bottostrapped } \\
\text { Mean\%Weight }\end{array}$ & $\begin{array}{c}\text { Lower 95\% } \\
\text { Confidence Limit }\end{array}$ & $\begin{array}{c}\text { Upper 95\% } \\
\text { Confidence Limit }\end{array}$ \\
\hline Newfoundland: & & & & \\
$\quad$ Atlantic cod & 3.1 & 3.2 & 1.7 & 4.8 \\
Capelin & 22.2 & 22.2 & 10.7 & 36.4 \\
Arctic cod & 42.6 & 42.6 & 27.2 & 57.6 \\
Energy Density & 1.4 & 1.4 & 1.3 & 1.4 \\
Gulf of St Lawrence: & & & & \\
Atlantic cod & 5.6 & 5.5 & 1.5 & 9.6 \\
Capelin & 46.3 & 45.1 & 23.6 & 4.5 \\
Arctic cod & 2.0 & 2.0 & - & 1.6 \\
Energy Density & 1.5 & 1.5 & 1.4 & \\
\hline
\end{tabular}

TABLE 7. Regression formulae used to estimate the percent wet weight of prey from prevalence measures for nearshore harp seals collected in eastern Newfoundland during 1982-93.

\begin{tabular}{llcc}
\hline \hline & \multicolumn{1}{c}{ Regression Formula } & $\mathrm{N}$ & $\mathrm{r}^{2}$ \\
\hline Atlantic cod & $\%$ Weight $=1.931+(0.206 \times P R)+\left(0.008 \times P R^{2}\right)$ & 24 & 0.885 \\
Capelin & $\%$ Weight $=3.229+(1.454 \times P R)+\left(0.007 \times P R^{2}\right)$ & 21 & 0.613 \\
Arctic cod & $\%$ Weight $=(1.133 \times P R)-0.978$ & 16 & 0.763 \\
\hline
\end{tabular}


the mean energy density of prey consumed in the Arctic was assumed to be the same as that used for eastern Newfoundland.

The consumption of individual prey species was estimated using the average proportion of each species in the diet. An estimate of the variance associated with the proportion of each species present was obtained by bootstrapping as explained above.

To estimate the sensitivity of the model to basic parameters, individual parameters were varied as described above and seal consumption in southern (eastern Newfoundland and Gulf of St. Lawrence) waters calculated. The parameters used in the initial and alternative runs are summarised in Table 9.

\section{Results}

\section{Total Consumption}

Total prey consumption by harp seals in the Northwest Atlantic was estimated to have increased from 3.6 million tons in 1981 to 6.9 million tons in 1994 (Fig. 3). The proportions of prey obtained in the Arctic and eastern Newfoundland areas were comparable (46\% and $40 \%$, respectively) while the Gulf of St. Lawrence accounted for $14 \%$ of the annual consumption. The amount of prey consumed in the southern areas almost doubled over the study period, rising from 1.45 to 2.79 million tons in eastern Newfoundland waters and from 498000 to 960000 tons in the Gulf of St. Lawrence.

TABLE 8. Estimated percent wet weights in the diet of harp seals in nearshore waters of eastern Newfoundland, 1981-89, derived from prevalence measures (Stenson et al., NWAFC, St. John's, Canada, unpubl. data).

\begin{tabular}{llrrrrrrr}
\hline \hline Season & Prey Species & 1981 & 1983 & 1984 & 1985 & 1987 & 1988 & 1989 \\
\hline \multirow{2}{*}{ Summer } & Atlantic cod & - & 3.2 & - & 2.1 & 4.6 & 2.7 & 6.2 \\
& Capelin & - & 50.1 & 17.3 & 49.9 & 30.7 & 31.3 & 24.5 \\
& Arctic cod & 72.5 & 19.0 & 27.8 & 0.4 & 25.6 & 36.8 & 41.8 \\
\multirow{2}{*}{ Sample Size } & & 60 & 379 & 16 & 321 & 212 & 195 & 114 \\
--1 Winter & Atlantic cod & 5.0 & 2.8 & 1.9 & 4.7 & 2.8 & 2.6 & 3.9 \\
& Capelin & 7.0 & 58.0 & 57.6 & 4.5 & 4.3 & 13.9 & 21.4 \\
& Arctic cod & 72.1 & 23.3 & 24.6 & 73.3 & 69.9 & 63.3 & 56.2 \\
& & 210 & 99 & 84 & 51 & 568 & 476 & 389 \\
\hline \multirow{2}{*}{ Sample Size } & & & & & & & &
\end{tabular}

TABLE 9. Parameters used during initial and alternate runs of the harp seal consumption model and the percent change in estimated consumption in southern Atlantic waters.

\begin{tabular}{lccc}
\hline \hline & & \multicolumn{2}{c}{ Alternate Model } \\
\cline { 3 - 4 } Parameter & \multicolumn{1}{c}{ Initial Model } & Parameters & $\begin{array}{c}\% \text { Change in } \\
\text { Consumption }\end{array}$ \\
\hline 1994 total population & 4.8 million & 4.5 million & $-12 \%$ \\
Activity factor & 2 & 2.5 & $+25 \%$ \\
$\begin{array}{l}\text { Juvenile energy } \\
(G P ; \text { Table 3) }\end{array}$ & Lavigne et al., 1986 & Olesiuk, 1993 & $-7 \%$ \\
Residency period & 15 November-15 June & 1 November-30 June & $+12 \%$ \\
\hline
\end{tabular}


These estimates of consumption were sensitive to changes in the model assumptions. Of those examined, the largest change occurred by altering the energetic cost of swimming and other normal activities. Increasing $A F$ by $25 \%$ from 2 to 2.5 resulted in a $25 \%$ increase in the energy required and, since the amount consumed was based upon the total energy required, a $25 \%$ increase in the estimated prey consumed (Fig. 4, Table 9). Smaller changes in the amount of prey consumed occurred when the population model and $G P$ were changed. Using the numbers-at-age derived from the population model

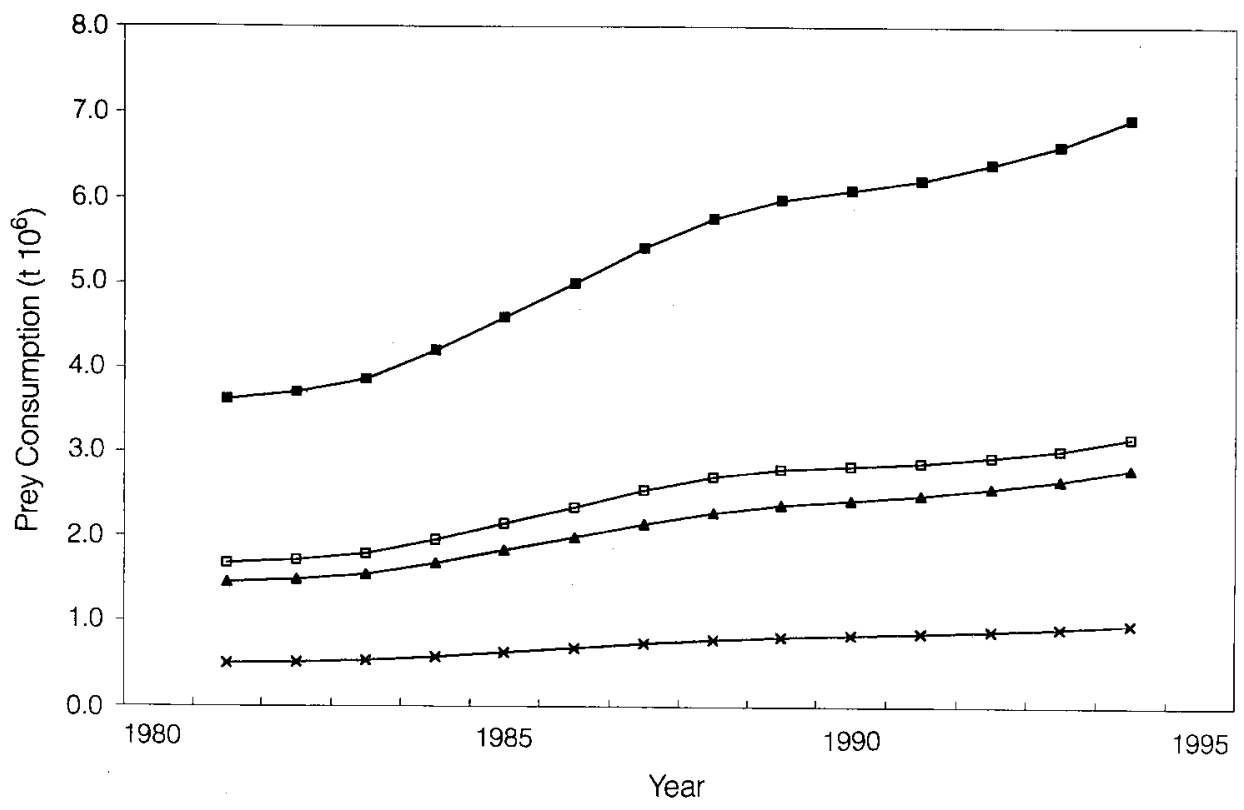

Fig. 3. Estimated prey consumption by harp seals in the Arctic ( $\square$ ) eastern Newfoundland $(\boldsymbol{\Delta})$, Gulf of St. Lawrence $(\times)$ and total Northwest Atlantic ( $\boldsymbol{\square})$.

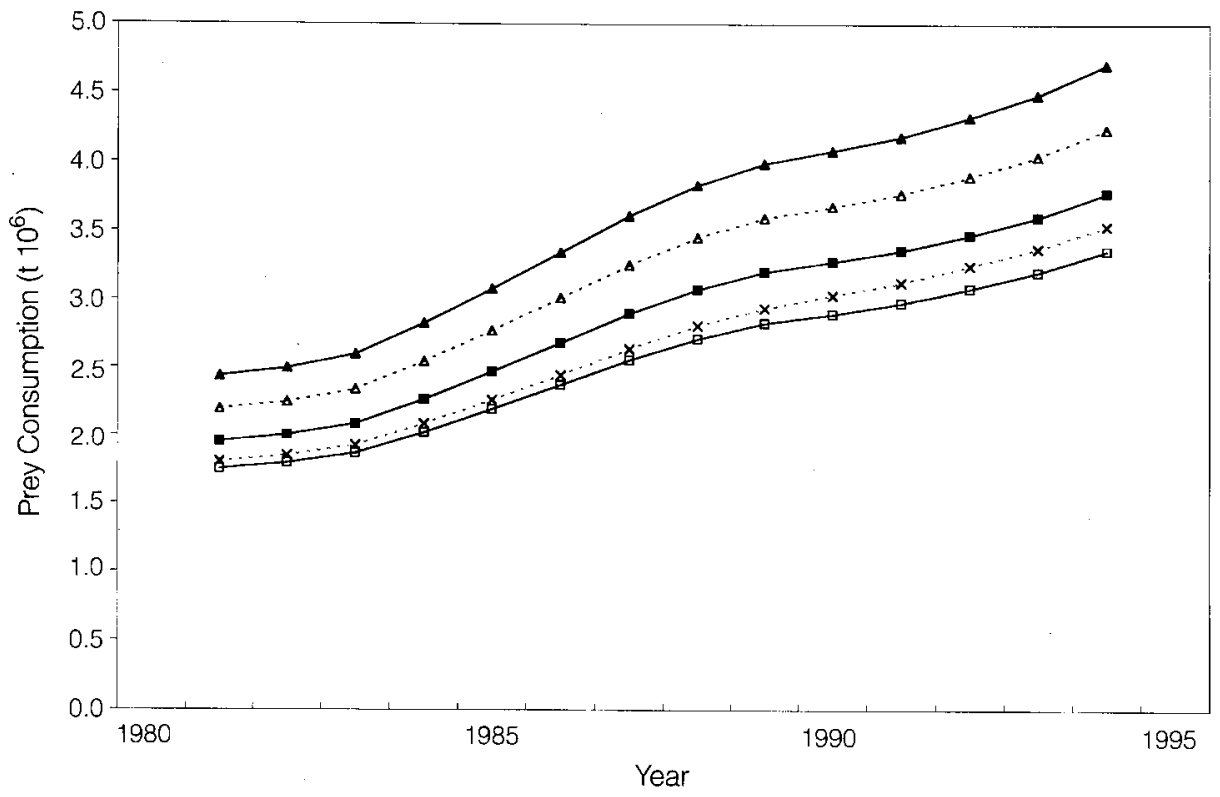

Fig. 4. Estimated prey consumption by harp seals in southern waters (Newfoundland and the Gulf of St. Lawrence) using initial ( $\square$ ) and alternate parameters for lower population $(\square)$ and energy requirements of juveniles $(\times)$, and higher estimates of activity factor $(2.5, \boldsymbol{\Delta})$, and residency period $\Delta$. See Table 9 for a description of the parameters used. 
with higher pup mortality and a lower overall population of 4.5 million (Shelton et al., 1996) decreased the estimate of consumption in southern waters during 1994 by $12 \%$ from 3.7 million tons to 3.3 million (Fig. 4, Table 9). Similarly, replacing the estimates of the increased energy requirement of juveniles obtained from Øritsland and Markussen (1990) with the lower estimates of Olesiuk (1993) resulted in a reduction of $7 \%$ in the consumption (Fig. 4, Table 9).

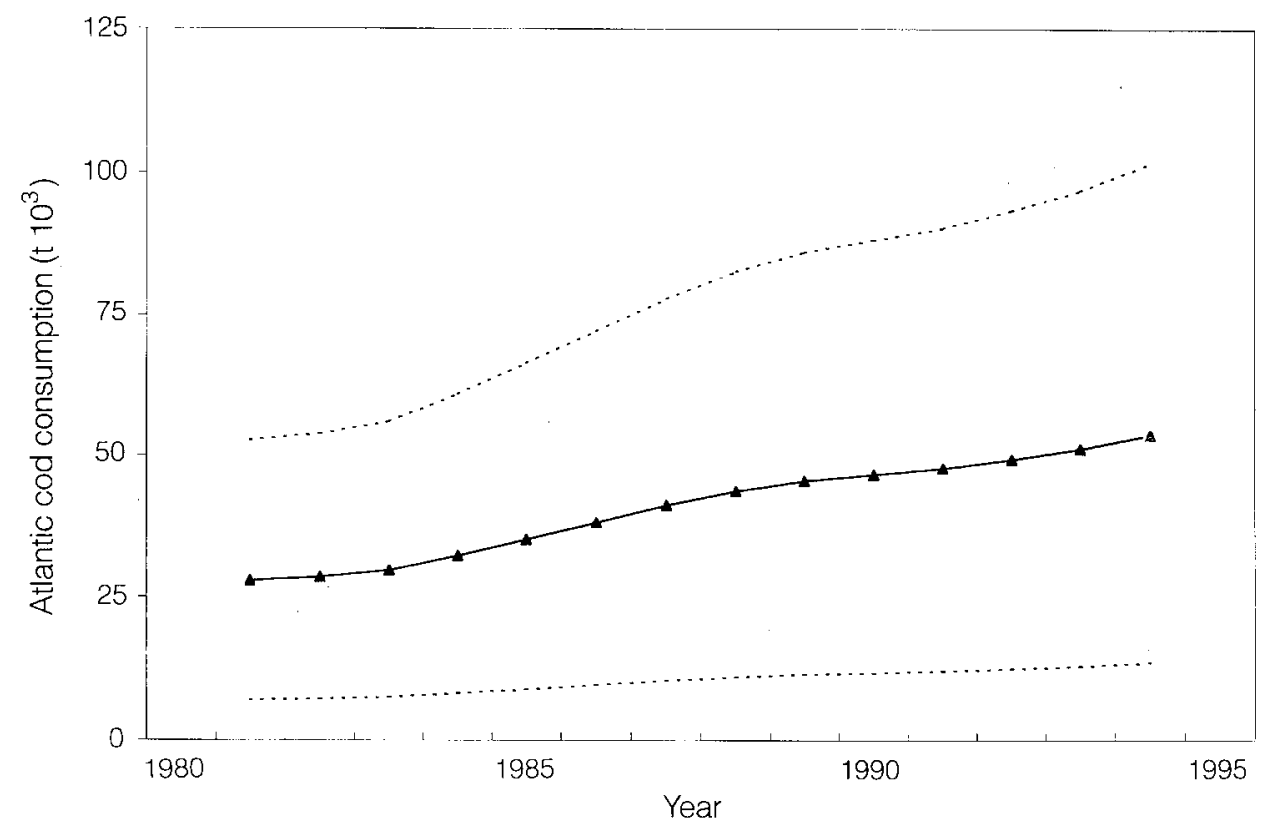

Fig. 5. Estimated consumption of Atlantic cod in the Gulf of St. Lawrence using the average diet (and 95\% C.I.).

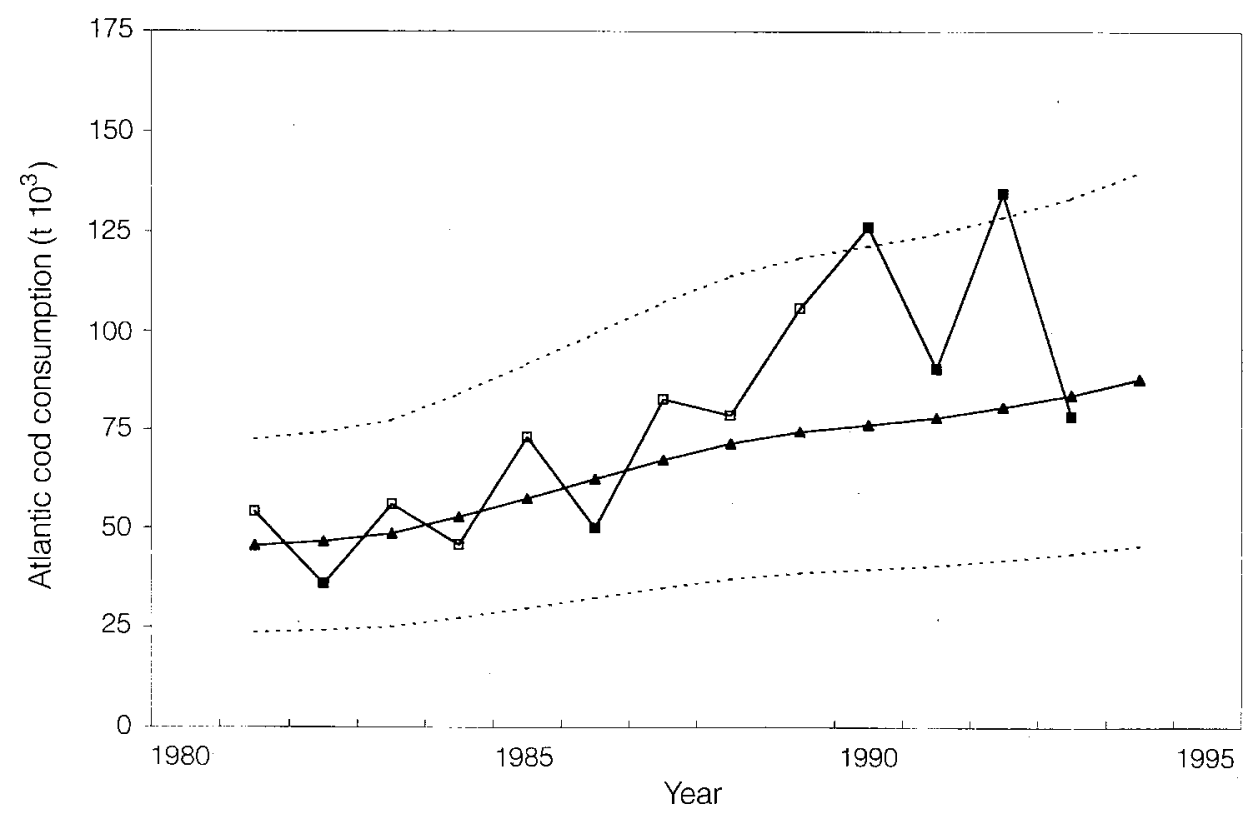

Fig. 6. Estimated consumption of Atlantic cod in eastern Newfoundland waters using average ( $\boldsymbol{\Delta}$ with $95 \%$ C.I.) and annual ( $\boldsymbol{\square})$ estimates of the diet. Open boxes indicate years for which wet weights were approximated using prevalence. 
Increasing the time during which seals are present in southern waters slightly (one month or $14 \%$ ) did not affect the estimate of overall consumption but did increase the estimate of consumption in the Gulf of St. Lawrence and Newfoundland by 12\% (Fig. 4, Table 9).

\section{Atlantic Cod Consumption}

Consumption of Atlantic cod in the Gulf of St. Lawrence was estimated to have increased from 28000 tons in 1981 to 54000 tons in 1994 (Fig. 5). Because of the large variability in the diet samples, the $95 \%$ confidence limits were wide, ranging from 14000 to 102000 in 1994.

Using the average proportion of Atlantic cod in the diet, consumption off eastern Newfoundland increased from 46000 to 88000 tons between 1981 and 1994 (Fig. 6). As in the Gulf of St. Lawrence, the variability in these estimates, indicated by the $95 \%$ confidence limits, was close to $50 \%$, ranging from 46000 to 140000 in 1994.

A slightly different pattern of Atlantic cod consumption in eastern Newfoundland was obtained when annual, seasonal and geographic variations in the diet were included (Fig. 6). Although estimates of consumption in individual years varied greatly, an apparent trend towards increased consumption of cod was present. From 1981 to 1988, consumption was similar to that predicted using the average diet. However, since 1989 these estimates were generally greater than those obtained using the average. For two years (1990 and 1992) the estimated consumption was slightly above the upper $95 \%$ confidence intervals. The proportion of cod in the diet for both of these years was derived directly from reconstructed weights and not approximated from prevalence data.

\section{Capelin Consumption}

Estimates of total consumption of capelin in the Gulf of St. Lawrence increased from approximately 230000 tons in 1981 to almost 445000 tons (95\% C.I. 208 000-727 000) in 1994 (Fig. 7). In Newfoundland waters, it rose from slightly over 321000 tons to 620000 tons $(95 \%$ C. I. $288000-$ 1.0 million) between 1981 and 1994 (Fig. 8).

Estimating annual capelin consumption incorporating seasonal and geographic effects on the diet, indicated that Newfoundland harp seals consumed large amounts of capelin in the early-1980s (e.g. over 850000 tons in 1982), but that consumption declined by 1986 to approximately 450000 tons.

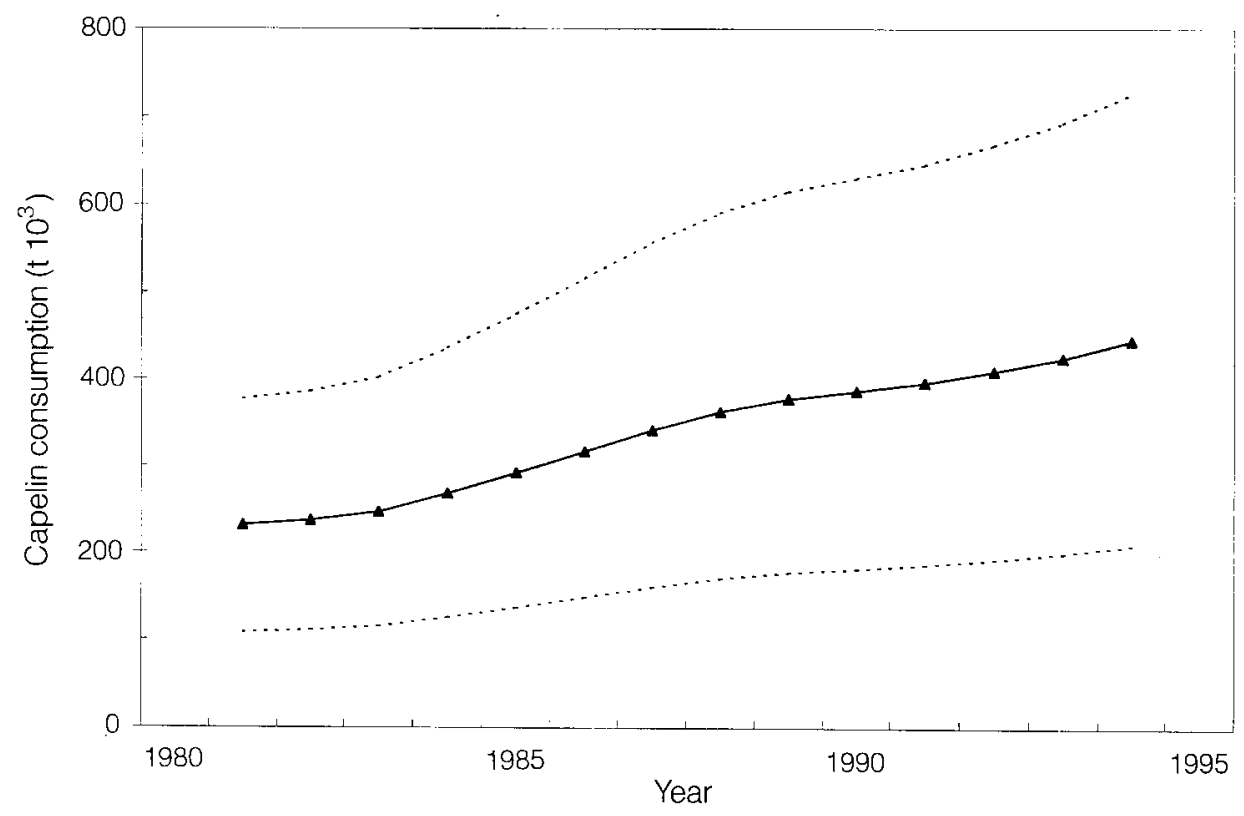

Fig. 7. Estimated consumption of capelin in the Gulf of St. Lawrence using the average diet (and 95\% C.I.). 


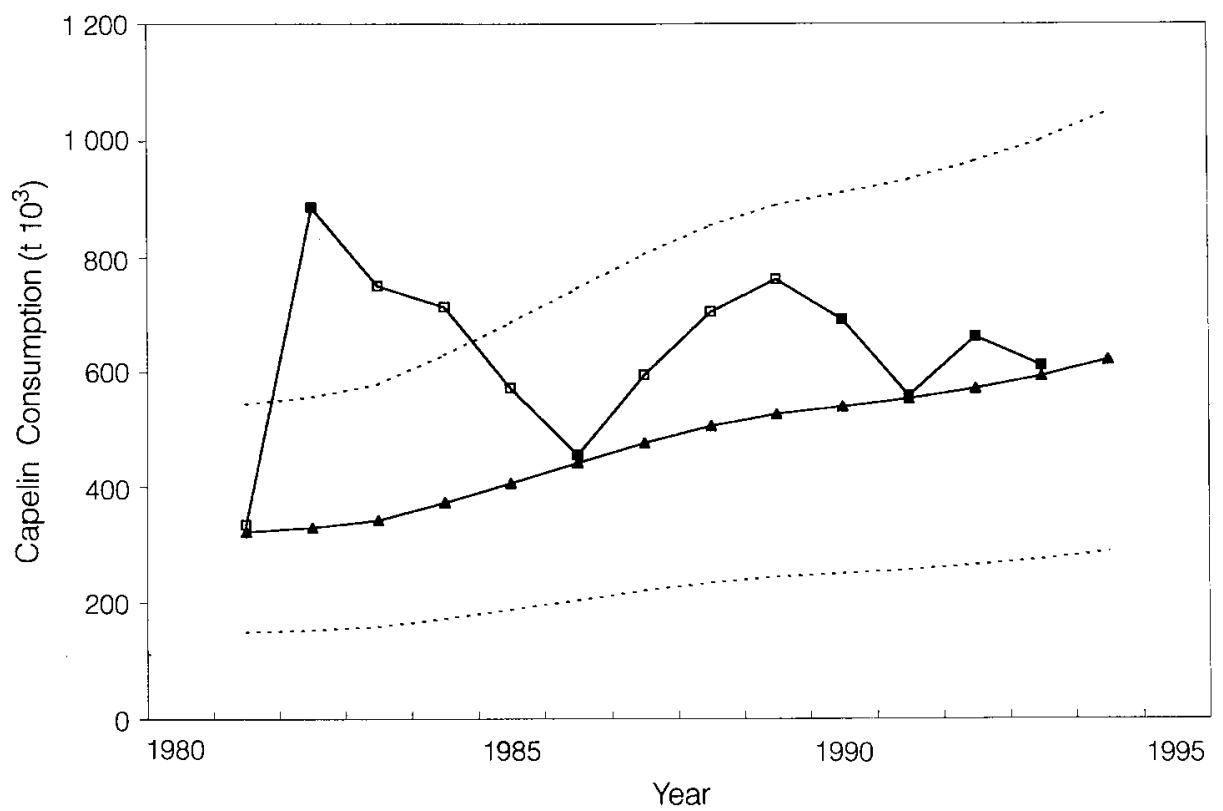

Fig. 8. Estimated consumption of capelin in eastern Newfoundland waters using average ( $\Delta$ with $95 \%$ C.I.) and annual ( $\boldsymbol{\square}$ ) estimates of the diet. Open boxes indicate years for which wet weights were approximated using prevalence.

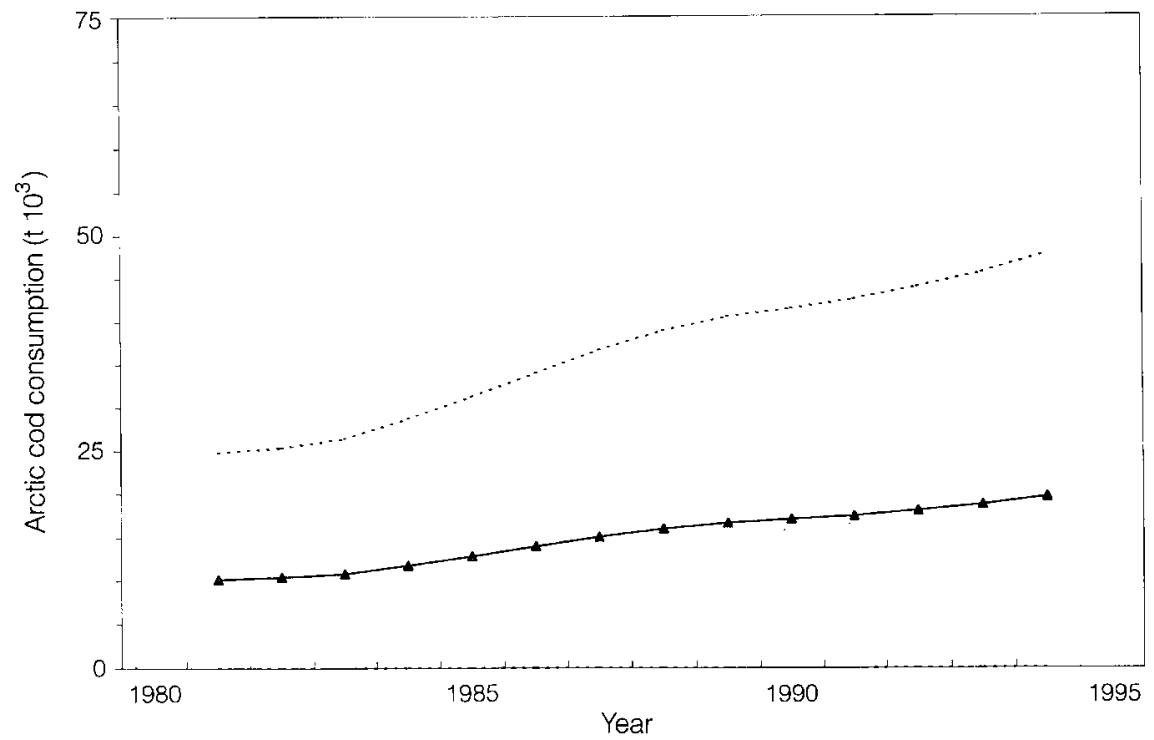

Fig.9. Estimated consumption of Arctic cod in the Gulf of St. Lawrence using the average diet (and $95 \%$ C.I.).

During the late-1980s and early-1990s capelin consumption fluctuated around 600000 tons (Fig. 8).

\section{Arctic Cod Consumption}

Relatively small amounts of Arctic cod were consumed by harp seals in the Gulf of St. Lawrence (Fig. 9), as expected based on the distribution of this Arctic fish. Consumption varied from 10000 tons in 1981 to 20000 tons in 1994. However, the variance associated with these estimates was large, ranging from zero (0) to 48000 tons in 1994. 


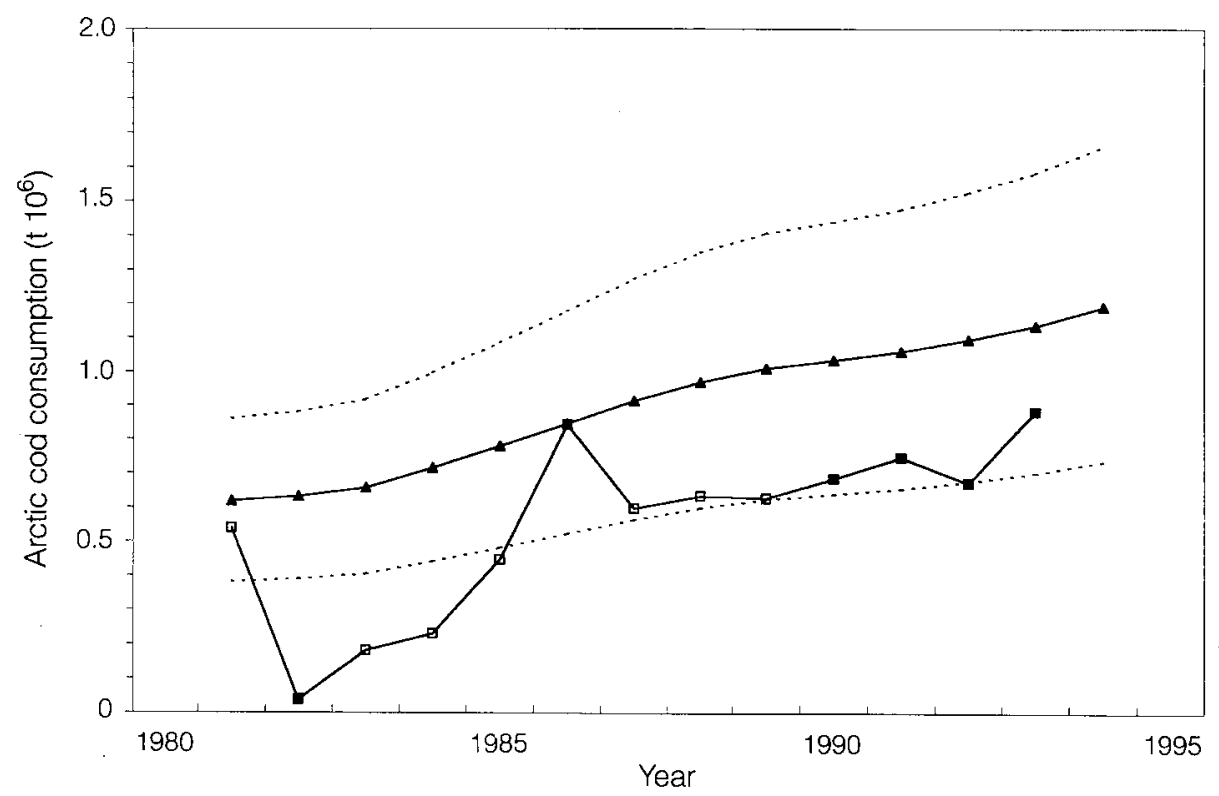

Fig. 10. Estimated consumption of Arctic cod in eastern Newfoundland waters using average ( $\boldsymbol{\Delta}$ with $95 \%$ C.I.) and annual (ם) estimates of the diet. Open boxes indicate years for which wet weights were approximated using prevalence.

More Arctic cod were consumed in eastern Newfoundland waters than either of the other two fish species. An estimated 1.2 million tons $(95 \%$ C.I. 73 000-1.7 million tons) were consumed in 1994. This was an increase of over $90 \%$ since 1981 (Fig. 10).

Annual proportions of Arctic cod in the diet varied such that model estimates of consumption were low in the early 1980 s (e.g. 45000 tons in 1982), but increased to over 840000 tons in 1986 (Fig. 10). Consumption was estimated to have remained over 600000 tons since the mid-1980s.

\section{Discussion}

This study presents preliminary estimates of total prey consumption by harp seals in the Northwest Atlantic and the amount of Atlantic cod, capelin and Arctic cod consumed in the Gulf of St. Lawrence and the waters of eastern Newfoundland. These estimates are based on the assumptions that: numbers-at-age can be determined from the population model described in Shelton et al. (1996); energy requirements are adequately estimated by the simple energy budget described; the amount of prey consumed equals the energy requirements of the population; information on the seasonal distri- bution of animals is described by the distributions assumed in the model (Table 1); and that the stomach samples (Tables 4-6) accurately reflect the proportion of each prey species in harp seal diet.

The estimates of population size used in this model were obtained from a population model incorporating age-specific reproductive rates and catches, together with independent estimates of pup production (Shelton et al., 1996). The estimates of the size and age structure of the population during the time period of this study depend upon the rate of pup mortality assumed in the model. Assuming that mortality is constant for all ages resulted in an estimate of 4.8 million (95\% C.I. 4.1-5.4; Warren et al., 1997) harp seals in 1994. However, if the mortality of pups is greater than that of older seals (e.g. 3 times), the point estimate may be as low as 4.5 million (Shelton et al., 1996). Although this represents a change in abundance of only $7 \%$, the change in age structure of the population resulted in a $12 \%$ change in consumption.

The model is also sensitive to the assumptions made when estimating the energy requirements of individuals and therefore, changes in any of the parameters used to estimate or scale the basal metabolic rate $(B M R)$ directly affect estimates of 
total consumption. For example, if the increased energy required by juveniles is closer to that reported by Olesiuk (1993) than the values used by Øritsland and Markussen (1990), the estimates of consumption will be reduced slightly (7\%). Similarly, the energetic costs of activity $(A F)$, which have been estimated to range from 1.7-3 BMR (Worthy, 1990), can have a large impact on these estimates. We used a conservative $A F$ of 2 . However, since this factor is a simple multiplier in the equation for energy requirements, altering this assumption could increase consumption by $50 \%$ (if adjusted to 3 ) or reduce it by $15 \%$ (if assumed to be as low as 1.7$)$.

In this model, we used the average body mass for harp seals during April. However, seals undergo periods of weight gain to build up energy stores and subsequently lose weight during the breeding and moulting periods (Chabot et al., 1996). Therefore, energy may be gained in one area or season and expended in another. In the Northwest Atlantic much of this weight gain appears to occur during the winter months while the weight loss occurs between March and May (Chabot et al., 1996). April body weights, which are similar to those observed when seals arrive from the Arctic, are near the lowest for the period during which seals are present in the southern areas. Thus, the energy requirements may be underestimated for the winter period. Estimating energy requirements based upon monthly weights may be one way to correct for seasonal changes in body mass (Nilssen et al., MS 1997). However, to do so requires samples from throughout the year or assumptions about weights in months for which there are no data.

Energy requirements in individual years may also differ from those estimated using body mass based upon collections made over a number of years. The data used in this study combine samples collected between 1979 and 1994. In recent years, however, mass at a given age is lower than in earlier in the time period (Chabot et al., 1996) which would result in slight overestimates of recent consumption.

In this study a relatively simple energy budget model was used to estimate individual energy requirements. Intuitively, a complex model incorporating seasonal changes in body mass and the costs of reproduction in energy requirements would appear to be more appropriate. However, a complex model requires estimation of additional parameters that may result in unpredictable interactions. Also, each additional parameter has an associated error that may reduce the precision of the model substantially. Recent studies indicate that although the energy costs of reproduction may be high for breeding females, these costs increase total energy requirements of the population by only 5\% (Olesiuk, 1993; Hammill and Mohn, MS 1994). Hammill and Mohn (MS 1994) found little difference between estimates of Atlantic cod consumption by grey seals using either a simple or more complex energy budget model. Overall, our estimates of annual per capita energy requirements are intermediate to values estimated previously for harp seals by Lavigne et al. (1985) and Markussen and Øritsland (1991) using more detailed energy budget models.

Estimating consumption based upon the amount of energy required assumes that all of the energy requirements of the predator are met. If this does not occur, the amount of prey consumed will be overestimated. The extremely poor condition of Barents Sea harp seals caught in gill nets along the Norwegian coast in 1988 (Nilssen et al., 1997) suggests that they did not meet their energy requirements. The poor condition of Northwest Atlantic harp seals in recent years (Chabot et al., 1996) may also indicate that they are not obtaining sufficient energy in some years.

Consumption of individual species is estimated as a proportion of the total consumption. Therefore, any changes in parameters affecting total consumption such as population size or energy requirements, will result in proportional changes in species consumption estimates.

Although estimates of consumption are sensitive to assumptions of population size and energy requirements, the potential range of changes in these parameters can be estimated using available data. Unfortunately, the uncertainty associated with the seasonal distribution of harp seals is more difficult to determine. The proportion of energy seals obtained from each geographical area was based on a distribution pattern derived primarily from anecdotal information and tag returns. This information may be biased since tag returns and sightings are more common in populated coastal areas or in areas with a tradition of seal hunting than in areas such as open, offshore waters. In addition, such information is difficult to quantify and does not 
provide insights into the offshore distribution of animals outside of the whelping and moulting periods. Fisher (1955) reported that the southward migration of harp seals may have been later in the 1950 s than in the early-1920s. In contrast, there have been a number of anecdotal reports indicating that harp seals have migrated southward earlier in recent years and remained longer (Stenson and Kavanagh, 1993; Stenson et al., NWAFC, St. John's, Canada, unpubl. data). Such changes will affect any estimates of consumption by increasing (or reducing) the proportion of energy obtained in southern waters.

Modifying the relative distribution of harp seals between eastern Newfoundland and the Gulf of St. Lawrence area will effect our estimates of consumption due to the geographical differences in the proportion of each species in the diet. For example, if additional energy is obtained from the Gulf of St. Lawrence, the higher proportion of cod and capelin in the diet would increase consumption estimates for these species while reducing that of Arctic cod.

The deployment of satellite transmitters provides one approach in which the distribution of seals can be examined in detail. Preliminary results from a study of the movements of 21 harp seals off eastern Newfoundland (Stenson and Sjare, MS 1997) indicate that the residency period (212 days) and variance (1 month) used in this model are reasonable. Data from these seals may also provide some indication of the relative importance of offshore and nearshore areas. However, similar information on the movements of harp seals in the Gulf of St. Lawrence are still required to quantify the distribution of harp seals throughout the year.

In order to estimate the consumption of individual prey species, it is necessary to assume that the diet of the population is adequately described by the stomach samples available. Information on the diet composition of harp seals in the Gulf of St. Lawrence was limited to a few samples in the upper St. Lawrence Estuary, the Magdalen Islands during the breeding period, and the southwest and west coasts of Newfoundland. These samples from Newfoundland suggest that cod form an important component of the harp seal diet, while the remaining samples from the Gulf of St. Lawrence indicate that insignificant quantities of cod are consumed. By using an average diet for Gulf of St. Lawrence harp seals, we assumed that the amount of energy obtained in these different areas is proportional to the number of areas sampled. For example, if the Gulf of St. Lawrence harp seals spend the majority of their time in the estuary, the estimates of cod consumption will be too large, but if they spend more time near the Newfoundland coast, they will be underestimates. More information is required on what proportion of the population is found along the west coast of Newfoundland, in the central Gulf, or in the estuary, and the amount of time these animals spend in each of these areas.

The diet information available for harp seals in eastern Newfoundland waters was much more extensive and indicated that there was considerable variation in the diet among years, seasons and geographical areas. Because the 'average' diet was based upon the mean of the 14 samples available, it was heavily weighted towards nearshore samples in recent years (1990-93). In contrast, the annual estimates incorporate each of the diets separately, weighted by season and the assumed nearshore/offshore distribution. This accounted for the differences observed between the consumption estimates using the two methods. Since the nearshore samples used for the 'average' diet contained higher proportions of Arctic cod and less capelin than the offshore samples, the estimates obtained using the average diet indicate that less capelin and more Arctic cod was consumed than those obtained using the annual estimates. Also, the higher proportion of capelin and less Arctic cod in the diet samples collected in the early-1980s than those from the 1990s suggest trends in consumption that are masked by using diet information averaged over several years.

In the absence of information on the relative distribution of harp seals we assumed that the proportion of energy obtained from areas represented by the nearshore and offshore diets were equal. Changes in this assumption will affect the estimates of consumption of some prey species significantly. For example, if the proportion of energy obtained by harp seals in the offshore was decreased from $50 \%$ to $30 \%$, estimates of Atlantic cod consumption in 1993 would decrease by approximately $17 \%$, while the estimate of capelin would decrease by $32 \%$, and Arctic cod would increase by over $38 \%$ due to the different diets observed in these two areas. 
Estimated wet weights of prey ingested were not available for all years used in this study. The proportion of each prey species in the diet estimated using the regressions provides only rough approximations of the diet for years when only prevalence measures were available. Complete reconstruction of the diet in these years or better statistical methods of estimating the proportion of the diet accounted for by each species in years for which only prevalence data are available, are necessary to determine if the estimates used here are appropriate.

The consumption estimates presented in this paper were restricted to a period (1981-94) for which there were reasonable data available on the diet of harp seals. It is possible to extrapolate back to 1955 when the population model begins, but this would require assumptions concerning the nature of the diet in earlier years. Given the variation observed over the time period of this model, this may not be appropriate. To determine the impact of harp seal predation on commercial fish species, estimates of recent consumption are the most important, and is the time period for which we have the best data. Predicting future levels of consumption is also difficult. The current rate of population growth may not be applicable if the recently observed reductions in reproductive rates continue (Sjare et al., 1996) and significant changes in the harvest levels of harp seals occur. Therefore, periodic estimates of pup production and monitoring of reproductive rates will be necessary in order to determine future population size. Also, the decline of capelin in the nearshore diet observed in the mid-1980s and recent increase in the importance of herring in the diet (Lawson and Stenson, 1995), illustrate the need to monitor diets on a regular basis in order to estimate the consumption of specific species.

By altering the basic parameters used in the model by fixed amounts, we were able to show the sensitivity of the consumption estimates to input assumptions. Although this provides us with an indication of the variability that occurs, the only source of uncertainty incorporated in these estimates is related to variation in the diet. To provide a more realistic estimate of the uncertainty associated with this model, error associated with estimating all of the parameters should be included. Shelton et al. (1997) presents a stochastic approach to quantifying the overall uncertainty associated with all of the parameters using Monte Carlo simulations.
Within the context of the above discussion, consumption of fish off eastern Newfoundland by harp seals has increased since 1981 and was estimated to be in the order of 1.2 million tons $(95 \%$ C.I. 735 000-1.7 million) of Arctic cod, 620000 tons (95\% C.I. $288000-1.0$ million) of capelin, and 88000 tons (95\% C.I. $46000-140$ 000) of Atlantic cod in 1994. In the Gulf, harp seals consumed an estimated 445000 tons (95\% C.I. 208 000-727 000) of capelin, 20000 tons (95\% C.I. 0-48 000) of Arctic cod, and 54000 tons (95\% C.I. 14 000-102 000) of Atlantic cod during 1994. The majority of the fish consumed by harp seals are $1020 \mathrm{~cm}$ in length (Lawson et al., 1995). These would be primarily juvenile Atlantic cod (1 and 2 year old) that are not recruited into the commercial fishery. The majority of capelin in this size range would be 1 and 2 year olds, but some 3 year olds which are taken by the commercial capelin fishery may be eaten by harp seals.

Attempts to assess the impact of harp seals on Atlantic cod stocks are beyond the scope of this paper. However, this study does indicate that harp seals may be a significant source of mortality for juvenile Atlantic cod, and an important predator on cod prey species. However, until our knowledge of the seasonal distribution of harp seals and annual, geographic, and seasonal variations in the diet are improved, these estimates should be considered preliminary and used with caution. In addition, the uncertainty associated with all of the parameters should be incorporated into the model in order to provide realistic estimates of consumption.

\section{Acknowledgements}

We thank D. McKinnon, D. Wakeham, W. Penney and J. F. Gosselin for their help in obtaining the basic data on population size, body weight and diets, D. Chabot for the morphometric data, W. Warren for advice on statistics, and the large number of friends and colleagues who provided suggestions which improved the model. We also thank two anonymous reviewers for their comments to clarify the manuscript. This project was funded, in part, by the DFO Northern Cod Science Program.

\section{Literature Cited}

ANON. 1986. Seals and sealing in Canada. A report of the Royal Commission. Ministry of Supply and Serv- 
ices. Ottawa, Canada.

BECK, G. G., M. O. HAMMILL and T. G. SMITH. 1993. Seasonal variation in the diet of harp seals (Phoca groenlandica) from the Gulf of St. Lawrence and western Hudson Strait. Can. J. Fish. Aquat. Sci., 50: $1363-1371$.

CHABOT, D., G. B. STENSON, and N. B. CADIGAN. 1996. Short- and long-term fluctuations in the size and condition of harp seal (Phoca groenlandica) in the Northwest Atlantic. NAFO Sci. Coun. Studies, 26: $15-32$.

EFRON, B. 1982. The jackknife, the bootstrap and other resampling plans. Society for Industrial and Applied Mathematics. $92 \mathrm{p}$.

EFRON, B. and R. J. TIBSHIRANI. 1993. An introduction to the Bootstrap. New York: Chapman \& Hall. $436 \mathrm{p}$.

FISHER, H. D. 1955. Utilization of harp seal populations. Trans. North Amer. Wildlife Conf., 20: 507-518.

HAMMILL, M. O. and R. MOHN. MS 1994. A model of grey seal predation on Atlantic cod on the Scotian Shelf and Gulf of St. Lawrence. DFO. Atl. Fish., Res. Doc. No. 75.

KAPEL, F. O. 1982. Trends in catches of harp and hooded seals in Greenland, 1939-1983. NAFO Sci. Coun. Studies, 10: 57-65.

KAPEL, F. O. 1995. Feeding ecology of harp and hooded seals in the Davis Strait - Baffin Bay region. In: Seals, whales, fish and man, A.S. Blix, Ø. Ultang, and L. Walløe (eds.), Elsevier Science B.V., p. 287-304.

KEIVER, K. M., K. RONALD, and F. W. BEAMISH. 1984. Metabolizable energy requirements for maintenance and faecal and urinary losses of juvenile harp seals (Phoca groenlandica). Can. J. Zool., 62: 769-776.

KLEIBER, M. 1975. The fire of life: An introduction to animal energetics. New York: Robert E. Krieger Publishing Co. $478 \mathrm{p}$.

LARSEN, F. MS 1985. Report on harp seal recoveries in Greenland, 1981-84. NAFO SCR Doc., No.13, Serial No. N947, 4 p.

LAVIGNE, D. M., S. INNES, R. E. A. STEWART, and G. A. J. WORTHY. 1985. An annual energy budget for northwest Atlantic harp seals. In: Marine Mammals and Fisheries, J.R. Beddington, R.J.H. Beverton \& D.M. Lavigne (eds), George Allen \& Unwin, London, p. 319-336.

LAWSON, J. W. and G. B. STENSON. 1995. Historic variation in the diet of harp seals (Phoca groenlandica) in the northwest Atlantic. In: Seals, whales, fish and man, A.S. Blix, Ø. Ultang, and L. Walløe (eds.), Elsevier Science B.V., p. 261-269.

LAWSON, J. W., G. B. STENSON and D. G. McKINNON. 1995. Diet of harp seals (Phoca groenlandica) in nearshore waters of the northwest Atlantic during 1990-1993. Can. J. Zool., 73: 1805-1818.

LAWSON, J. W., E. NOSEWORTHY, and E. H. MILLER. 1997. Variation in assimilation and digestive effi- ciency of captive harp seals (Phoca groenlandica) on different diets. Can. J. Zool., 75: 1285-1291.

LAWSON, J. W., A. MAGALHÃES, and E. H. MILLER. 1998. Important prey species of marine vertebrate predators in the Northwest Atlantic: proximate composition and energy density. Mar. Ecol. Prog. Ser., (in press).

LAWSON, J. W., and G. B. STENSON. 1997. Diet of Northwest Atlantic harp seals (Phoca groenlandica) in offshore areas. Can. J. Zool., 75: 2095-2106.

MARKUSSEN, N. H. and N. A. ØRITSLAND. 1991. Food energy requirements of the harp seal (Phoca groenlandica) population in the Barents and White Seas. Polar Res., 10: 603-608.

MOHN, R. and W. D. BOWEN. 1996. Grey seal predation on eastern Scotian Shelf: modelling the impact on Atlantic cod. Can. J. Fish. Aquat. Sci., 53: 27222738.

MURIE, D. J. and D. M. LAVIGNE. 1991. Food consumption of wintering harp seals, Phoca groenlandica, in the St. Lawrence estuary, Canada. Can. J. Zool., 69: 1289-1296.

NILSSEN, K. T. 1995. Seasonal distribution, condition and feeding habits of Barents Sea harp seals (Phoca groenlandica). In: Seals, whales, fish and man, A. S. Blix, Ø. Ultang, and L. Walløe (eds.), Elsevier Science B.V., p. 241-254.

NILSSEN, K. T., T. HAUG, P. E. GROTNES, and V. POTELOV. 1997. Seasonal variation in body condition of adult Barents Sea harp seals (Phoca groenlandica). J. Northw. Atl. Fish. Sci., 22: 17-25 (this volume).

NILSSEN, K. T., O.-P. PEDERSEN, L. P. FOLKOW, and T. HAUG. MS 1997. Food consumption estimates of Barents Sea harp seals. ICES C.M. Doc., No. CC:01.

NORDØY, E. S., L. P. FOLKOW, P.-E., MÅRTENSSON, and A. S. BLIX. 1995a. Food requirements of Northeast Atlantic minke whales. In: Seals, whales, fish and man, A.S. Blix, Ø. Ultang, and L. Walløe (eds.), Elsevier Science B.V., p. 307-317.

NORD $\emptyset$ Y, E. S., P.-E., MÅRTENSSON, A. R. FOLKOW, L. P. FOLKOW, and A.S. BLIX. 1995b. Food consumption of the Northeast Atlantic stock of harp seals. In: Seals, whales, fish and man, A. S. Blix, $\varnothing$. Ultang, and L. Walløe (eds.), Elsevier Science B.V., p. 255-260.

OLESIUK, P. F. 1993. Annual prey consumption by harbour seals (Phoca vitulina) in the Strait of Georgia, British Columbia. Fish. Bull., 91: 491-515.

ØRITSLAND, N. A. and N. H. MARKUSSEN. 1990. Outline of a physiologically-based model for population energetics. Ecol. Modelling, 52: 267-288.

RONALD, K., K. M. KEIVER, F. W. H. BEAMISH and R. Frank. 1984. Energy requirements for maintenance and faecal and urinary losses of the grey seal (Halichoerus grypus). Can. J. Zool., 62: 1101-1105.

RYG, M. and N. A. ØRITSLAND. 1991. Estimates of energy expenditure and energy consumption of 
ringed seals (Phoca hispida) throughout the year. Polar Res., 10: 595-601.

SERGEANT, D. E. 1965. Migrations of harp seals Pagophilus groenlandicus (Erxleben) in the Northwest Atlantic. J. Fish. Res. Board Can., 22: 433-463.

SERGEANT, D. E. 1973. Feeding, growth, and productivity of northwest Atlantic harp seals (Pagophilus groenlandicus). J. Fish. Res. Board Can., 30: 17-29.

SERGEANT, D. E. 1991. Harp seals, man and ice. Can. Spec. Pub. Fish. Aquat. Sci., 114: 153 p.

SHELTON, P. A., G. B. STENSON, B. L. SJARE and W. WARREN. 1996. Model estimates of harp seal numbers-at-age for the Northwest Atlantic. NAFO Sci. Coun. Studies, 26: 1-14.

SHELTON, P. A., W. G. WARREN, G. B. STENSON and J. W. LAWSON. 1997. Quantifying some of the major sources of uncertainty associated with estimates of harp seal prey consumption. Part II: Uncertainty in consumption estimates associated with population size, residency, energy requirement and diet. J. Northw. Atl. Fish. Sci., 22: 303-315 (this volume).

SJARE, B. L., G. B. STENSON, and W. G. WARREN.
1996. Summary of female harp seal reproductive parameters in the northwest Atlantic. NAFO Sci. Coun. Studies, 26: 41-46.

SMITH, T. G., M. H. HAMMILL, D.W. DOIDGE, T. CARTIER and G. S. SLENO. 1979. Marine mammal studies in southeastern Baffin Island. Can. MS Rep. Fish. Aquat. Sci. 1552: 70 p.

STENSON, G. B. and D. J. KAVANAGH. 1993. Distribution of harp and hooded seals in offshore waters of Newfoundland. NAFO Sci. Coun. Studies, 21: $121-142$.

STENSON, G. B. and B. SJARE. MS 1997. Seasonal distribution of harp seals, Phoca groenlandica, in the Northwest Atlantic. ICES C.M. Doc., No. CC:10.

WARREN, W. G., P. A. SHELTON and G. B. STENSON. 1997. Quantifying some of the major sources of uncertainty associated with estimates of harp seal prey consumption. Part I: Uncertainty in the estimates of harp seal population size. J. Northw. Atl. Fish. Sci., 22: 289-302 (this volume).

WORTHY, G. A. J. 1990. Nutritional energetics in marine mammals: addendums. In: CRC handbook of marine mammal medicine: Health, disease, and rehabilitation, L. A. Dierauf (ed.), Boca Raton, Florida: CRC Press, p. 489-520. 